International Journal of Instruction e-ISSN: 1308-1470 • www.e-iji.net
July $2020 \bullet$ Vol.13, No.3

p-ISSN: 1694-609X

pp. $555-570$

Received: 01/06/2019

Revision: 13/02/2020

Accepted: 20/02/2020

OnlineFirst:03/05/2020

\title{
Effectiveness of Process Oriented Guided Inquiry Learning with Peer Feedback on Achieving Students' Mathematical Reasoning Capabilities
}

\section{Kartono}

Semarang State University, Indonesia, kartono.mat@mail.unnes.ac.id

Rena Yuliantika Shora

Semarang State University, Indonesia, renayuliantikas@gmail.com

Mathematical reasoning ability is the ability to think logically to get a conclusion. This study aims to analyzing the effectiveness of Process Oriented Guided Inquiry Learning (POGIL) with Peer Feedback towards the students' achievement of mathematical reasoning abilities. The population in this study were 7th-grade students in one junior high school in Semarang in the academic year 2018/2019. This research is quantitative research. Sampling is done using random sampling techniques. The results showed that (1) the average mathematical reasoning ability of students in POGIL with Peer Feedback was more than or equal to the minimum specified completeness criteria, namely 65 , (2) the proportion of students who reached 65 in POGIL with Peer Feedback more than or equal to 75\%, (3) the average mathematical reasoning ability of students in POGIL with Peer Feedback is more than the average mathematical reasoning ability of students in Discovery Learning, and (4) the proportion of students who achieve grades 65 in POGIL with Peer Feedback is more than the proportion of students who reach 65 in Discovery Learning, (5) self-regulated learning of mathematics affects 30\% of students' mathematical reasoning abilities.

Keywords: effectiveness, mathematical reasoning ability, process oriented guided inquiry learning, peer feedback, self-regulated learning

\section{INTRODUCTION}

Education is a bridge to gain knowledge and skills that will be useful for the future. One of the educational efforts of concern is the development of mathematics education. According to Nunes \& Csapo (2011: 17) mathematics is one of the oldest disciplines and offers valid content for the school curriculum. Mathematical material and mathematical reasoning are two interrelated things, namely mathematical reasoning is needed to understand mathematical material, and through learning mathematics to train and sharpen mathematical reasoning.

Citation: Kartono, \& Shora, R. Y. (2020). Effectiveness of Process Oriented Guided Inquiry Learning with Peer Feedback on Achieving Students' Mathematical Reasoning Capabilities . International Journal of Instruction, 13(3), 555-570. https://doi.org/10.29333/iji.2020.13338a 
Rizqy \& Surya (2017: 3528) mathematical reasoning ability is an activity, reasoning process, thinking ability to get a conclusion or make a truth a new statement. This is in line with Saleh et al. (2018: 44) states a conclusion can be drawn through reasoning by looking at each relationship of the argument or information available. Erdem (2015: 124) also says that mathematical knowledge is achieved through reasoning rather than experimentation or observation.

Adegoke (2013: 54) states that students who have good mathematical reasoning skills will be successful in achieving mathematics learning outcomes. Therefore, Adegoke suggested that teachers must have an intervention program to improve students' mathematical reasoning abilities for their mathematical achievements. In addition, Sumarsih et al. (2018: 8) also states that students can develop analogy and logical thinking then the student will be able to solve the problems easily. Sukirwan et al. (2018: 1) states that the complexity of the causes of reasoning includes abilities that are not easily achieved by students. The researcher also conducted a preliminary study on the achievement of the mathematical reasoning abilities of the seventh-grade students in one junior high school in Semarang in the academic year 2018/2019. The following is one of the comparison questions regarding the indicators submitting suspicions and providing logical reasons.

Five buffaloes eat 5 times the area of grass in 5 days. If the speed of eating each buffalo's grass is the same, how many days does it take for 3 buffaloes to spend 3 times the grass on the soccer field?

Based on the analysis results, from 32 students, 3 students answered correctly that it took 5 days for 3 buffaloes to spend 3 times the grass on the soccer field. While 28 students answered that it took 3 days for 3 buffaloes to spend 3 times the grass field of football. They see a pattern in the problem which states that five buffaloes eat 5 times the area of grass in 5 days. So they answer like that. Only one student did not answer the question. Based on this, it can be seen that the students' mathematical reasoning ability is still low. Almost all students answer the same thing. Students have not been able to reason about known statements. So that students cannot provide the right answers.

Mathematical reasoning ability is important to grow so that students are able to understand mathematical concepts well. Therefore, there needs to be an effort in learning activities so that the achievement of students' mathematical values can be more optimal. The learning model that will be used to be adapted to the material taught and cognitive size to train students' mathematical reasoning abilities. Recognizing the conditions described above, students' mathematical reasoning abilities need attention in mathematics learning. One learning model that is expected to be able to overcome these problems is the POGIL (Process Oriented Guided Inquiry) learning model.

POGIL is a combination of guided inquiry learning and cooperative learning (Sen et al., 2015: 54). The learning method in POGIL emphasizes collaborative aspects of constructivism that use in the cycle of exploration, concept discovery, and application of concepts during knowledge building (Rege et al., 2016; Trevathan et al., 2014). Avsec and Kocijancic (2014: 1436) inquiry-based learning is an inductive pedagogy that 
enables high-level reasoning skills to develop knowledge, to develop high-level reasoning skills and contemporary learning. Meanwhile, Kurniashih et al. (2019: 2). Guided inquiry is one of the important components of the contextual learning model and constructivism that is developing rapidly in the reform of the educational process in Indonesia today.

POGIL is included in cooperative learning, students work in teams of 3-4 people, design activities to build cognitive abilities, and develop skills during the learning process. In this study to help support teamwork in group discussions, the researchers used print media in the form of student worksheets. Napitupulu (2017: 167) states the need for students' development worksheets in secondary school learning to help students reasoning in understanding concepts. According to Irwanto et al. (2018: 779) POGIL can improve student achievement and students are directed to obtain a concept with a process-oriented, more constructive and interactive. De Gale \& Boisselle (2015: 58) also stated that POGIL is a collaborative learning strategy that can provide concrete experience benefits so that it can help students learn better. Hanson (2013: 31) There are seven stages of POGIL, namely engaging, elicit, explore, explain, elaborate, elaborate and extend, and evaluated. Each group member in POGIL learning has their respective roles, namely managers, spokespersons, minutes, and strategy analysts.

In this study, the final learning activity will be formative feedback, namely peer feedback for students who must make improvements. Peer feedback is formative feedback where the process of giving feedback is aided by peers whereas formative feedback is feedback that is used to improve learning and occur during learning (Naylor et al., 2014: 4). So, before peer feedback is given, students will be given formative assessment in the form of a multiple-choice test first. Sumantri and Satriani (2016: 518) state that a formative multiple-choice test can encourage students to remember, interpret and recall other people's ideas. Whereas according to Irons (2008: 7) formative feedback is very potential and has full strength in building learning devices. Stahlberg (2016: 85) states that peer feedback is a promising way to improve learning. The existence of peer feedback, students will more easily understand the next material in learning.

The development of the mindset of students in solving problems by not relying on others is one of the learning objectives. The condition of learning activities of students independently and not dependent on others is also called self-regulated learning of students. This is in line with Fadlelmula (2010: 364) which states that self-regulated learning is the key concept to succeed in academic learning. Sudirman et al. (2017: 250) self-regulated learning is the ability of children to carry out learning activities responsibly which is driven by self-motivation and achievement of learning as well and optimally. According to Sari et al. (2017: 2) the purpose of self-regulated learning is to teach students to learn on their own and in turn empower them in the learning process regardless of their context or learning environment.

In this study, indicators of mathematical reasoning ability used are indicators according to Rizqy \& Surya, which are as follows. 
Table 1

Indicators of Mathematical Reasoning Abilities

\begin{tabular}{ll}
\hline Indicator & character problem \\
$\begin{array}{l}\text { put forward a } \\
\text { presumption }\end{array}$ & $\begin{array}{l}\text { The main character of this problem is asking students to submit allegations } \\
\text { which are then proven by displaying various concepts mastered by students } \\
\text { that have to do with the problem. }\end{array}$ \\
\hline $\begin{array}{l}\text { compile evidence } \\
\text { and give reasons }\end{array}$ & $\begin{array}{l}\text { the main character of this question is more on how students express the } \\
\text { reason for the truth of a statement. }\end{array}$ \\
\hline $\begin{array}{l}\text { check the validity } \\
\text { of an argument }\end{array}$ & $\begin{array}{l}\text { the main character of this problem usually starts by stating the answer to a } \\
\text { problem or statement that was deliberately made wrong. The aim is only to } \\
\text { encourage the accuracy of the students to check the validity of an argument. }\end{array}$ \\
\hline $\begin{array}{l}\text { make a decision } \\
\text { from a statement }\end{array}$ & $\begin{array}{l}\text { Making decisions from a statement, the main character of this problem is the } \\
\text { existence of two or more statements where students are required to make } \\
\text { decisions based on logical reasons. }\end{array}$ \\
\hline
\end{tabular}

While the indicators of self-regulated learning used are indicators according to Hidayati \& Listyani, namely 1) dependence on others; (2) have confidence; (3) discipline behavior; (4) have a sense of responsibility; (5) behave based on their own initiative; and (6) exercise self-control.

Based on the background above, the formulation of the problem to be examined in this study is (1) whether Process Oriented Guided Inquiry Learning with Peer Feedback is effective in achieving the students' mathematical reasoning abilities ?; (2) is there any influence on self-regulated learning of mathematics learning on students' mathematical reasoning abilities? The purpose of this study is (1) to determine the learning of Process Oriented Guided Inquiry Learning with Peer Feedback effective on the achievement of students 'mathematical reasoning abilities (2) to determine the influence self-regulated learning of mathematics on students' mathematical reasoning abilities.

\section{METHOD}

\section{Research Design}

The research design used in this study is a posttest-only control design, which is giving the final test after the learning activities have been completed. posttest-only control design was used to compare groups that were more experimental groups, then compared to one or more control groups that did not receive the treatment.

Table 2

Posttest-Only Control Design

\begin{tabular}{lll}
\hline Class & Treatment & \\
\hline A & POGIL with Peer Feedback & $\mathrm{O}_{1}$ \\
B & - & $\mathrm{O}_{2}$ \\
\hline
\end{tabular}

Sampling in this study was carried out by simple random sampling technique. The method used to obtain data is tests, and questionnaires. Preliminary tests are used to obtain data on the initial abilities of students who become the study sample. The data were analyzed to find out that the two samples had the same initial ability. Test methods are used to obtain data on mathematical reasoning abilities in social arithmetic material. 
The value of mathematical reasoning ability is then processed to test the research hypothesis. The results of the questionnaire were used to determine the effect of selfregulated learning of mathematics on students' mathematical reasoning abilities.

\section{Participants}

The population in this study were 7th-grade students in one of the junior high schools in Semarang in the academic year 2018/2019. In this study, one class was chosen as the experimental class, namely class 7A by using Process Oriented Guided Inquiry Learning with Peer Feedback and one class as a control class namely 7C by using Discovery Learning according to teacher learning conducted at school. Class $7 \mathrm{E}$ was chosen as a trial class. The learning material used in this study is social arithmetic material. The number of students in the experimental class and the control class is the same, namely 32 students. Based on calculations using SPSS 23.0 software, the results of the normality and homogeneity tests of the initial experimental class data, control class, and trial class indicate that the initial data is normally distributed and there is no difference in variance between the three classes. The results of the similarity of the initial data mean also showed that the initial abilities of the three classes were not significantly different. The following is a graph of the average preliminary results of the three classes.

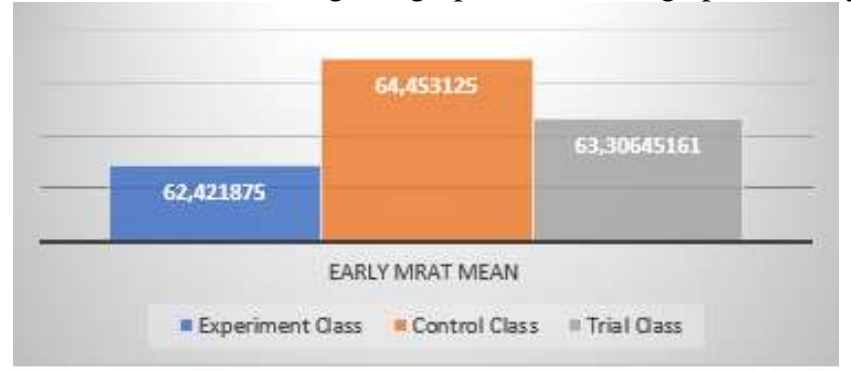

Figure 1

The Average Initial Test of Mathematical Reasoning Ability

\section{Data Collection Instruments}

The instrument used in this study was a test of mathematical reasoning ability consisting of 6 questions. Before the test instrument was given to the experimental class and the control class, the test instrument was validated by 5 experts to then calculate the value of content validity for each item using the V Aiken's formula. After all the items are valid, then they are tested in the trial class to find out the reliability, the level of difficulty, and the difference in power of the questions. The instrument is in the form of essay questions so that the reliability of the test questions is more precisely calculated using Cronbach's alpha. The instrument reliability testing using the Cronbach's alpha because this research instrument assessment scores took the form of a scale (Anatol \& Hariharan, 2015: 14). The results of the analysis show the reliability value of the test instrument is 0.742 . Selfregulated learning of mathematics questionnaire instrument consisted of 29 items. After being tested and analyzed the value of validity and reliability, the reliability value obtained is 0.858 . The results of the validity show that 20 items are valid and are 
suitable for use.. Based on the analysis, 4 valid questions were obtained to be used as tests of mathematical reasoning abilities.

\section{Procedure}

The study was conducted for 1 month, starting from January to February 2019. During the instruction, students in the experimental group were taught by using POGIL with the Peer Feedback method, while students in the control group were taught using Discovery Learning teaching methods according to the learning used by a math teacher at a research school. In this treatment, both groups were taught by the same teacher and used the same learning device. Table 3 shows a syntax of POGIL with Peer Feedback method adapted from Hanson (2013: 31)

Table 3

Syntax of POGIL with Peer Feedback

\begin{tabular}{|c|c|c|}
\hline & Syntax & Details of Activities \\
\hline 1. & $\begin{array}{l}\text { Identify the need for learning } \\
\text { (engage) }\end{array}$ & $\begin{array}{l}\text { The teacher presents the learning objectives and presents } \\
\text { interesting issues related to the material. }\end{array}$ \\
\hline 2. & Linking previous knowledge (elicit) & The teacher gives questions related to prior knowledge. \\
\hline 3. & Exploration (explore) & $\begin{array}{l}\text { The teacher explains the learning model used and the source } \\
\text { of the material used to explore the problems at hand. }\end{array}$ \\
\hline 4. & $\begin{array}{l}\text { Understanding and concept } \\
\text { formation (explain) }\end{array}$ & $\begin{array}{l}\text { The teacher guides students to find concepts through a } \\
\text { worksheet. }\end{array}$ \\
\hline 5. & $\begin{array}{l}\text { Practice of applying knowledge } \\
\text { (elaborate) }\end{array}$ & $\begin{array}{l}\text { The teacher guides students to answer the concept } \\
\text { application. }\end{array}$ \\
\hline 6. & $\begin{array}{l}\text { Apply knowledge to new concepts } \\
\text { (elaborate and extend) }\end{array}$ & $\begin{array}{l}\text { The teacher guides students to answer the application of } \\
\text { more complicated concepts. }\end{array}$ \\
\hline 7. & $\begin{array}{l}\text { Reflection in the process } \\
\text { (evaluated) }\end{array}$ & $\begin{array}{l}\text { The teacher provides formative assessment activities and } \\
\text { continues peer feedback to increase students' knowledge } \\
\text { about the material being studied. }\end{array}$ \\
\hline
\end{tabular}

\section{Data Analysis}

In this study, quantitative data analysis used parametric statistics because the data came from populations that were normally distributed. Descriptive statistics including mean, standard deviation, maximum and minimum scores were used. The t-test is used to test the average test results of the mathematical reasoning abilities of the experimental class students and test the average difference between the experimental class and the control class, the z-test is used to test the proportion of students who reach 65 in the experimental class and test the difference in the proportion of participants students who reach 65 between the experimental class and the control class. Simple linear regression is used to calculate the effect of self-regulated learning of mathematics on mathematical reasoning abilities of students who take POGIL with Peer Feedback. In this study, a significant level of $5 \%$ is used. Calculation of normality test, homogeneity test, and simple linear regression test in this study using SPSS 23.0 software.

\section{FINDINGS}

Based on the results of the test of mathematical reasoning ability consisting of 4 questions, obtained descriptive statistics between two classes such as the following. 
Table 4

Descriptive Statistics

\begin{tabular}{llllll}
\hline Group & $\mathrm{N}$ & Minimum & Maximum & Mean & Std. Deviation \\
\hline A (experimental) & 32 & 57,50 & 100,00 & 73,1250 & 9,77571 \\
C (control) & 32 & 50,00 & 87,50 & 68,2031 & 9,82168 \\
Valid N (listwise) & 32 & & & & \\
\hline
\end{tabular}

Based on the Table 4 , the average test results of the mathematical reasoning abilities of the experimental class students were greater than the control class with a difference of 4.9219. In addition, based on the results of the minimum and maximum values, it was found that the experimental class had a minimum and maximum value greater than the control class. It can be seen that students in experimental groups were more superior than students in the control group after the implementation of POGIL with Peer Feedback. Based on the table, the standard deviation of the experimental class is less than the standard deviation of the control class. This shows that the control class variance is greater than the experimental class. The difference in standard deviation between the two groups is very small, which is equal to 0,04597 . However, based on the results of calculations using SPSS 23.0 the variances of the both groups did not differ significantly.

The analysis of the results of the posttest value of the students 'mathematical reasoning abilities aims to determine the results of the students' mathematical reasoning abilities which are described based on the indicators. The average test of mathematical reasoning abilities based on indicators is presented in Table 5 as follows

Table 5

Average Mathematical Reasoning Ability Test

\begin{tabular}{llll}
\hline Number & Indicators of Mathematical Reasoning Ability & Experiment Class & Control Class \\
\hline 1. & put forward a presumption & 9,4375 & 9,15625 \\
2. & compile evidence and give reasons & 5,375 & 4,5 \\
3. & check the validity of an argument & 5,0625 & 4,8125 \\
4. & make a decision from a statement & 9,375 & 8,8125 \\
\hline
\end{tabular}

Based on Table 5 above, it is known that for each indicator of mathematical reasoning ability, the class that has learned Process Oriented Guided Inquiry Learning with Peer Feedback is superior to the class that has Discovery Learning. The highest difference is in the indicator of providing evidence and giving reasons and then followed by indicators making decisions from a statement. In the indicator submitting a presumption and checking the validity of an argument there is no significant difference.

Based on the Table 5, it appears that the differences in mathematical reasoning abilities between the experimental class and the control class in the first, second, third, and fourth indicators are $2.8125 \%, 8.75 \%, 2.5 \%$, and $5.625 \%$ respectively. The biggest difference occurs in the second indicator, which is compiling evidence and giving reasons. In this indicator, there is a difference of $8.75 \%$ between the experimental class and the control class. This is because in the control class, students do not understand the purpose of the problem. While the smallest difference occurs in the indicator checking the validity of the argument. In this indicator, there is a difference between the experimental class and the control class $2.5 \%$. This is because students in the 
experimental class and the control class are used to working on the problem by writing the concept of the formula to be used for calculation.

Table 6

The Result of The Test of Normality

\begin{tabular}{|c|c|c|c|c|c|c|}
\hline \multicolumn{7}{|l|}{ Tests of Normality } \\
\hline & \multicolumn{3}{|c|}{ Kolmogorov-Smirnov $^{\mathrm{a}}$} & \multicolumn{3}{|c|}{ Shapiro-Wilk } \\
\hline & Statistic & df & Sig. & Statistic & df & Sig. \\
\hline experimental_class &, 150 & 32 &, 063 & 941 & 32 & 081 \\
\hline control_class & ,081 & 32 &, $200^{*}$ & ,979 & 32 &, 772 \\
\hline experimental_control & ,099 & 64 &, 192 & ,982 & 64 & ,454 \\
\hline
\end{tabular}

*. This is a lower bound of the true significance.

a. Lilliefors Significance Correction

Based on the SPSS normality test results provide the Kolmogorov-Smirnov and Shapiro-Wilk tests. These two tests are the same in that they are both testing for normality, however, the Shapiro-Wilk test is known to have more power in detecting differences from normality for small sample sizes (Field, 2018: 253). In this study the sample size is relatively small, so the normality test uses Shapiro-Wilk.

Posttest results of experimental class mathematical reasoning ability indicate that data is normally distributed because the p-value of $0.081>0.05$. Therefore, calculations using parametric statistics can be used to test hypotheses 1 and 2, namely the average test of one sample and the test of the proportion of one sample.

Hypothesis 1 test or the average test of one sample proposed in this study are:

$H_{0}$ : The average test results of mathematical reasoning abilities of students who take POGIL with peer feedback less than or equal to 65.

$H_{1}$ : The average test results of mathematical reasoning abilities of students who take POGIL with peer feedback more than 65.

The calculation of the hypothesis test 1 uses the one-party average test (right party) and uses the $t$ test. Based on level of significance 0.05 and $\mathrm{df}=32-1=31$, obtained

$t_{\text {table }}=1,6955$, and $t_{\text {count }}=4.990967$. Therefore, because $t_{\text {count }}>t_{\text {table }}$, then $H_{0}$ is rejected. So, it can be concluded that the average mathematical reasoning ability of students who take POGIL with Peer Feedback is more than 64.5.

Hypothesis 2 test or the test of the proportion of one sample proposed in this study are:

$H_{0}$ : Students who take POGIL with Peer Feedback incomplete in proportion, ie if less than or equal to $75 \%$ of the number of students participating in POGIL with Peer Feedback reaches a value of 65

$H_{1}$ : Students who take POGIL with Peer Feedback complete in proportion, ie if more than $75 \%$ of the number of students participating in POGIL with Peer Feedback reaches a value of 65 
The hypothesis 2 test uses the proportion test of one party, namely the proportion test of the right side and using the $z$ test. Based on level of significance 0.05 obtained $z_{\text {cownt }}=1.687214$, and $z_{\text {table }}=1.645$. Therefore, because $z_{\text {count }}>z_{\text {table }}$, then $H_{0}$ is rejected. So, it can be concluded that the proportion of students who achieved the value of 65 learning with the POGIL model with Peer Feedback was more than 0.745 .

Based on the test results of the experimental class mathematical reasoning ability and the control class indicate that the data is normally distributed. The results also show that the variances of the groups did not differ significantly. Therefore, parametric statistical calculations can be used to test hypotheses 3 and 4, namely the test of the average difference and the test of the proportions difference.

Hypothesis 3 test or the test of the average difference proposed in this study are:

$H_{0}$ : The average test results of mathematical reasoning abilities of students who take POGIL with Peer Feedback are less than or equal to the average test results of mathematical reasoning abilities of students who take Discovery Learning

$H_{1}$ : The average test results of mathematical reasoning abilities of students who take POGIL with Peer Feedback are better than the average test results of mathematical reasoning abilities of students who take Discovery Learning

The calculation of hypothesis 3 uses the right-hand average difference test using the $t$ test. The difference test results on average with level of significance 0.05 and $\mathrm{df}=32+$

$32-2=62$, obtained $t_{\text {table }}=1.6698$, and $t_{\text {count }}=2.00919$. Based on this, it is obtained $t_{\text {count }}>t_{\text {table }}$, then $H_{0}$ is rejected. So, the average mathematical reasoning ability of students who take POGIL with Peer Feedback is better than the average mathematical reasoning abilities of students in Discovery Learning.

Hypothesis 4 test or the test of the proportions difference proposed in this study are:

$H_{0}$ : The proportion of students who reaches a value of 65 in POGIL with Peer Feedback are less than or equal to the proportion of students who reaches a value of 65 in Discovery Learning

$H_{1}$ : The proportion of students who reaches a value of 65 in POGIL with Peer Feedback are better than the proportion of students who reaches a value of 65 in Discovery Learning

The calculation of hypothesis 4 uses the right proportion test using the $z$ test. The test results of the difference in proportions with level of significance 0.05 , obtained $z_{\text {table }}=1.645$, and $z_{\text {count }}=1.814229$. Based on this, $z_{\text {count }}>z_{\text {table }}$ is obtained, then $H_{0}$ is rejected. So, the proportion of students who reaches a value of 65 in 
POGIL with Peer Feedback is better than the proportion of students who reaches a value of 65 in Discovery Learning.

The results of the study of the level of independence of mathematics learning towards the mathematical reasoning abilities of students in the experimental class, the results obtained in the following table are obtained.

Table 7

The Result of The Independence Questionnaire Learning Mathematics

\begin{tabular}{lll}
\hline Category & Frequency & Percentage \\
\hline High & 14 & $43,75 \%$ \\
Moderate & 16 & $50 \%$ \\
Low & 2 & $6,25 \%$ \\
\hline Total & 32 & $100 \%$ \\
\hline
\end{tabular}

Based on these data, out of 32 students, 14 students were included in the high level of mathematics learning independence, 16 students included the moderate category, and 2 students were included in the low category. In addition, the average independence of mathematics learning of students is 58,8438 . So based on the maximum value of the questionnaire that is 80 , it can be said that overall, the level of self-regulated learning of students is quite high.

Table 8

Normality Test Results of The Regression Model

Tests of Normality

\begin{tabular}{lllllll}
\hline & \multicolumn{4}{l}{ Kolmogorov-Smirnov $^{\text {a }}$} & \multicolumn{3}{l}{ Shapiro-Wilk } \\
\cline { 2 - 7 } & Statistic & df & Sig. & Statistic & df & Sig. \\
\hline Unstandardized Residual &, 142 & 32 &, 098 &, 934 & 32 &, 061 \\
\hline
\end{tabular}

*. This is a lower bound of the true significance.

a. Lilliefors Significance Correction

The test of the effect of self-regulated learning of mathematics on the mathematical reasoning abilities of students in the experimental class was carried out using a simple linear regression test. The normality test in the regression model is used to test whether the residual values generated from the regression are normally distributed or not. A good regression model is one that has a normally distributed residual value. Based on the Shapiro-Wilk test output in Table 8, it can be seen that the p-value of 0.061>0.05. Then it can be concluded that the residual value is normally distributed.

The testing steps include, linearity test, simple linear regression equation, significance test, and coefficient of determination. Using SPSS 23.0 results are obtained as follows.

Table 9

ANOVA $^{\mathrm{a}}$

\begin{tabular}{lllllll}
\hline Model & & Sum of Squares & df & Mean Square & F & Sig. \\
\hline 1 & Regression & 955,621 & 1 & 955,621 & 14,285 &, $001^{\mathrm{b}}$ \\
& Residual & 2006,879 & 30 & 66,896 & & \\
& Total & 2962,500 & 31 & & & \\
\hline
\end{tabular}

a. Dependent Variable: A

b. Predictors: (Constant), questionnaire 
Based on the output of linearity test in the ANOVA Table 9, the p-value of $0.001<0.05$. So, this shows the existence of linearity in the relationship of the two variables or it can also be said this regression model can be used to predict the mathematical reasoning ability variable.

A simple linear regression equation can be read in the following table.

Table 10

Coefficients $^{\mathrm{a}}$

\begin{tabular}{llllllll}
\hline & & \multicolumn{2}{l}{$\begin{array}{l}\text { Unstandardized } \\
\text { Coefficients }\end{array}$} & \multicolumn{2}{l}{$\begin{array}{l}\text { Standardized } \\
\text { Coefficients }\end{array}$} & \\
\cline { 3 - 5 } Model & & B & Std. Error & Beta & T & Sig. \\
\hline 1 & (Constant) & 36,919 & 9,688 & & 3,811 &, 001 \\
& questionnaire &, 615 &, 163 &, 568 & 3,780 &, 001 \\
\hline
\end{tabular}

a. Dependent Variable: A

In the Unstandardized Coefficients column and Constants and questionnaires a value $=$ 36.919 and $b=0.615$. So the regression equation is $\mathrm{Y}^{\wedge}=36,919+0.615 \mathrm{X}$. Because the regression coefficient value is positive $(+)$, it means that the self-regulated learning of mathematics variable $(\mathrm{X})$ has a positive effect on the students' mathematical reasoning ability variable (Y). In other words, the higher the level of self-regulated learning of mathematics, the higher the mathematical reasoning abilities of students.

Hypothesis 5 test or the test of the effects proposed in this study are:

$H_{0}$ : There is no significant effect of self-regulated learning of mathematics variable $(\mathrm{X})$ on the students' mathematical reasoning ability variable (Y).

$H_{1}$ : There is a significant effect of self-regulated learning of mathematics variable (X) on the students' mathematical reasoning ability variable (Y).

Based on the output it is known that the p-value for self-regulated learning of mathematics variable can be seen in the questionnaire row which is $0.001<0.05$. So this shows that there is a significant effect of self-regulated learning of mathematics variable (X) on the students' mathematical reasoning ability variable (Y).

Linear regression determination coefficient is used to see the influence of self-regulated learning of mathematics on students' mathematical reasoning abilities. The coefficient of determination can be seen in Table 10 .

Table 11

Model Summary

\begin{tabular}{lllll}
\hline Model & $\mathrm{R}$ & R Square & Adjusted R Square & Std. Error of the Estimate \\
\hline 1 &, $568^{\mathrm{a}}$ &, 323 &, 300 & 8,17899 \\
\hline
\end{tabular}

a. Predictors: (Constant), questionnaire

Based on the output of the Model Summary, the magnitude of the correlation value (R) is equal to 0.568 and the value of Adjusted $\mathrm{R}$ Square $=0.300=30 \%$ is obtained. This 
value indicates that the $\mathrm{X}$ variable (self-regulated learning of mathematics) affects the $\mathrm{Y}$ variable (students' mathematical reasoning ability) by $30 \%$, that means self-regulated learning makes a small contribution to mathematical reasoning ability.

\section{DISCUSSION}

Based on the results of hypothesis 1 test, it was found that the average mathematical reasoning abilities of students in POGIL with Peer Feedback reached a minimum completeness criterion of 65 . In the hypothesis 2 test, the proportion of students who achieved 65 in POGIL with Peer Feedback reached 75\%. Based on this, it can be concluded that POGIL with Peer Feedback is able to make students achieve mastery learning in the questions of mathematical reasoning. This is in accordance with the research of Harahap et al. (2017: 5) states that there is an increase in students' mathematical reasoning abilities after being given an inquiry learning model. Hanib et al. (2017) which states that POGIL can improve learning completeness in high-level thinking skills. In addition, Walker and Warfa (2017: 11) suggest that in POGIL, students have higher achievement and reduce the risk of learning failure by about $30 \%$.

POGIL learning with Peer Feedback focuses on finding material concepts that are being studied by the students themselves. In the process of finding concepts, students can exchange ideas through group activities in completing the student worksheets. As Daubenmire \& Bunce (2014: 98) said that when developing students' conceptual understanding abilities, there needed to be more questions to broaden their discussion. POGIL implementation with little variation in this case giving worksheets can cause significant differences in learning outcomes. This is in line with Riwayati \& Destania (2018: 32) which states that the worksheets that are developed have potential effects, this can be seen based on the average value of students' mathematical reasoning abilities in good categories. Meanwhile, Purnomo \& Abadi (2015: 271) in their research applied POGIL with a worksheet on K-13 learning to develop student competencies.

Meanwhile, to make students all active in learning, in group activities each member of the group is given a role so that they are more responsible for their group assignments. Giving roles for each group member also makes students more enthusiastic in participating in class learning. The roles received by each group member for each meeting are different so that students get different responsibilities. This is in accordance with Piaget's theory that the learning process is an active process, because knowledge is formed from within the subject of learning so it is necessary to create a learning condition that allows children to learn on their own and without pressure. In addition, Farda et al. (2017) also states that giving responsibility in the form of roles to each group member influences the success of mathematics learning.

At the end of learning, students who have not completed the formative test are given feedback activities in the form of peer feedback in remedial learning. In peer feedback activities, students who do not understand the material being studied will get help from their friends who already understand the material they have not mastered. So that these students will better understand the material being studied and after being given advanced formative tests, the learners complete the indicators being measured. This is in 
accordance with the results of Reinholz (2018) study that giving peer feedback can improve the problem-solving process in mathematics learning. The study shows that peer feedback can improve mathematical high thinking skills.

In the control class given Discovery Learning, learning is carried out in groups. However, the collaboration between students in groups is still lacking because there is no clear division of tasks. In the process of discovering the concept of the material being studied, the worksheet is carried out by students who are dominant in the group. According to Riwayati \& Destania (2018: 30) students can develop thinking patterns to maximize mathematical reasoning skills. Based on this, it can be interpreted that if the worksheet is only done by one student, only those students whose mathematical reasoning abilities will develop. This resulted in other students not absorbing the knowledge gained, causing the test results of the students 'mathematical reasoning abilities in the control class to be lower when compared with the results of tests of students' mathematical reasoning abilities in the experimental class.

Factors that can be the cause of differences in the results of tests of mathematical reasoning abilities of students who have learned Process Oriented Guided Inquiry Learning with Peer Feedback and students who have Discovery Learning learning include (1) students carry out mathematics learning enthusiastically and without pressure, so the subject matter is acceptable; (2) in the Process Oriented Guided Inquiry Learning with Peer Feedback, the teacher provides a learning experience designed in understanding the material and building his own knowledge with discussion and teacher guidance. So that students are easier to remember the material being studied; (3) giving roles to each group member makes students more responsible for completing tasks given for group success, so that there are no dominant students in the group; (4) the existence of peer feedback makes students better understand the material that has not been mastered. In addition, peer feedback also helps students improve collaboration in learning mathematics and trains students to help each other in their learning activities.

Based on the description above, it can be concluded that the learning of Process Oriented Guided Inquiry Learning with Peer Feedback is effective towards achieving students' mathematical reasoning abilities because they meet the criteria. This is in line with the research of Farda et al. (2017) which states that POGIL with ethnomatematic nuances assisted by worksheet is effective against mathematical communication skills. The difference in the research with this research lies in the provision of assistance and measured mathematical abilities. however, the research together measures high-level mathematical abilities.

The influence of self-regulated learning of mathematics on students' mathematical reasoning ability is due to POGIL with Peer Feedback, students who have good selfregulated learning of mathematics are more interested and enthusiastic about the material being taught. Self-regulated learning of mathematics is related to motivation where the learning process is supported by the activities of the objectives to be achieved (Veas et al., 2016: 595). However, self-regulated learning of mathematics has an insufficient influence on students' mathematical reasoning abilities in the experimental class. This can be seen from Adjusted R Square of 30\% or less than 50\%. That is, the 
variations that occur in the mathematical reasoning abilities of $30 \%$ students are influenced by self-regulated learning of mathematics in the equation $Y=36.919+0.615$ X. Meanwhile, the remaining $70 \%$ is influenced by other variables. Sutrisno et al. (2019: 5 ) in his research suggests that self-regulated learning has a direct positive effect of 0.23 on the ability to think logically. This shows that the logical thinking ability is influenced by self-regulated learning.

\section{CONCLUSION AND SUGGESTION}

Based on the results of research and discussion, it was found that Process Oriented Guided Inquiry Learning with Peer Feedback was effective in achieving the mathematical reasoning abilities of students in arithmetic because it met the following criteria, (1) the average test results of mathematical reasoning abilities of students who attended POGIL with Peer Feedback more than or equal to 65; (2) students who take POGIL with Peer Feedback complete in proportion, if at least $75 \%$ of the number of students participating in POGIL with Peer Feedback reaches 65; (3) the average test results of mathematical reasoning abilities of students who take POGIL with Peer Feedback are better than the average test results of mathematical reasoning abilities of students who take Discovery Learning; (4) the proportion of students who reaches a value of 65 in POGIL with Peer Feedback is better than the proportion of students who reaches a value of 65 in Discovery Learning. In addition, it was obtained self-regulated learning towards the mathematical reasoning abilities of students in the class that participated in POGIL with Peer Feedback of $30 \%$.

Based on conclusions, the researcher gave the following suggestions; (1) It is better that in the next research, data retrieval of mathematics learning independence be carried out before and after being treated POGIL with Peer Feedback so that there can be increased self-regulated learning of mathematics, (2) the implementation of POGIL with Peer Feedback will be better if implemented on the subject matter at least 4 meetings, so that when rolling each group member can play a role in all four responsibilities in POGIL.

\section{REFERENCES}

Adegoke, \& Benson, A. (2013). Modelling the relationship between mathematical reasoning ability and mathematics attainment. $J$ of Edu and Practice, 4(17), 54-61.

Anatol, T., \& Hariharan, S. (2015). Reliability of the evaluation of students' answers to essay-type questions. West Indian Med Journal, 58(1), 13-16.

Daubenmire, P. L., \& Diane, M. B. (2014). What do students experience during POGIL instruction? Washington: East Carolina Univ.

De Gale, S., \& Boisselle, L. N. (2015). The effect of POGIL on academic performance and academic confidence. Science Education International, 26(1), 56-61.

Erdem, E., \& Ramazan, G. (2015). An analysis of seventh-grade students' mathematical reasoning. Çukurova Üniversitesi Eğitim Fakültesi Dergisi, 44(1), 123-142.

Fadlelmula, F. K. (2010). Mathematical problem solving and sel-regulated learning. International Journal of Learning, 17(3), 364-372. 
Farda, H., Zaenuri, Z., \& Sugiarto, S. (2017). Effectiveness of POGIL learning model with ethnomathematics nuance assisted by student worksheet toward student mathematical communication skill. Unnes J of Mathematics Education, 6(2), 223-230.

Field, A. (2018). Discovering statistics using IBM SPSS statistics. London: SAGE.

Hanib, M. Tofan, Suhadi, \& Sri Endah Indriwati. (2017). Science processing skill improvement through POGIL Model. Jurnal Pendidikan Sains, 5(4), 118-122.

Hanson, D. (2013). Instructor's guide to process oriented guided inquiry learning. Hampton: Pacific Crest.

Irons, A. (2008). Enhancing learning through formative assessment and feedback assessment. New York: Routledge.

Irwanto, Saputro, A. D., Rohaeti, E., \& Prodjosantoso, A. K. (2018). Promoting critical thinking and problem solving skills of preservice elementary teachers through processoriented guided-inquiry learning (POGIL). Int Journal of Instruction, 11(4), 777-794.

Kurniashih, R., Syarifuddin, H., \& Darmansyah, D. (2019). The influence of guided inquiry learning model on students' mathematical problem solving ability. Advances in Social Science, Education and Humanities Research, 178, 1-5.

Naylor, R., Baik, C., Asmar, C., \& Watty, K. (2014). Good feedback practices: Prompts and guidelines for reviewing and enhancing feedback for students. Australia: Pusat Pendidikan Tinggi Universitas Melbourne.

Napitupulu, E. E. (2017). Analyzing the teaching and learning of mathematical reasoning skills in secondary school. Asian Social Science, 13(12), 167-173.

Nunes, T., \& Csapó, B. (2011). Developing and assessing mathematical reasoning. In B. Csapó, \& M. Szendrei (Eds.), Framework for diagnostic assessment of mathematics (pp. 17-56). Budapest: Nemzeti Tankönyvkiadó.

Purnomo, Mega E. R., \& Agus M. A. (2015). The implementation of POGIL in mathematics learning process to develop students' competence within curriculum 2013. Proceeding of International Conference on Research, Implementation and Education of Mathematics and Sciences. Yogyakarta: Yogyakarta State University.

Rege, P., Havaldar, F., \& Shaikh, G. (2016). An effective use of POGIL in improving academic performance of students and their approach in organic chemistry. International Journal of Science and Research Methodology, 4(1), 45-61.

Reinholz, D. L. (2018). Peer feedback for learning mathematics. American Mathematical Monthly, 125(7), 653-658.

Riwayati, S., \& Destania, Y. (2018). Design of internet integrated students worksheet for developing the ability of mathematical reasoning. Advances in Social Science, Education and Humanities Research, 295, 30-33. 
Rizqi, N. R., \& Surya, E. (2017). An analysis of students' mathematical reasoning ability in VIII grade of sabilina tembung junior high school. International Journal of Advance Research and Innovative Ideas in Education, 3(2), 3527-3533.

Saleh, Muhamad, Rully Charitas I.P., Muhammad Isa, \& Murni. (2018). Improving the reasoning ability of elementary school student through the Indonesian realistic mathematics education. Journal on Mathematics Education, 9(1), 41-54.

Sari, F. A, Yindari, I. A. V., \& Fakhrudin. (2017). The application of problem based learning model to improve mathematical literacy skill and the independent learning of student. Journal of Physics, 812(1), 1-7.

Sen, S., Ayhan Y., \& Omer, G. (2015). The effect of process oriented guided inquiry learning environment on students' self-regulated learning skills. Problems of Education in the $21^{\text {st }}$ Century, 66, 54-65.

Stahlberg, N. (2016). Writing, calculating and peer feedback in a mathematicallyoriented course for process engineers: Raising motivation and initiating processes of thinking and learning. Journal of Academic Writing, 6(1), 84-97.

Sudirman, M., Fatimah, S., \& Jupri, A. (2017). Improving problem solving skill and self-regulated learning of senior high school students through scientific approach using quantum learning strategy. Int J of Sci and App Sci, Conference Series, 2(1), 249-255.

Sukirwan, Darhim, \& Herman, T. (2018). Analysis of students' mathematical reasoning. Journal of Physics, 948(1), 1-8.

Sumantri, M., \& Satriani, R. (2016). The effect of formative testing and self-directed learning on mathematics learning outcomes. Int E J of Elementary Edu, 8(3), 507-524.

Sumarsih, Budiyono, \& Indriati, D. (2018). Profile of mathematical reasoning ability of 8th grade students seen from communicational ability, basic skills, connection, and logical thinking. IOP Conf. Series: Journal of Physics: Conf. Series 1008, 012078.

Sutrisno J. A. B., Margono, G., \& Rahayu, W. (2019). The logical thinking ability: mathematical disposition and self-regulated learning. IOP Conf. Series: Journal of Physics: Conf. Series, 1155, 012092.

Trevathan, J., Myers, T., \& Gray, H. (2014). Scaling-up process-oriented guided inquiry learning techniques for teaching large information systems courses. Journal of Learning Design, 7(3), 23-38.

Veas, Alejandro, R Gilar, \& P Minao. (2016). The influence of gender, intellectual ability, academic self-concept, self regulation, learning strategies, popularity and parent involvement in early adolescence. Int $J$ of Inf and Education Technology, 6(8), 591-597.

Walker, L., \& Warfa, A. -R. M. (2017). Process oriented guided inquiry learning (POGIL) marginally effects student achievement measures but substantially increases the odds of passing a course. PLoS ONE, 12(10), 1-17. 